\title{
A New Reading of the Three Dialogues in Mishnah Avodah Zarah*
}

\author{
Amit GVaryahu
}

"Rabbi Benaya said: One should always dwell deep in mishnayot. For if he knocks, they will reveal to him - if [on the door of] study, study; if [on the door of] Aggadah, Aggadah."1

Mishnah Avodah Zarah discusses and describes the laws pertaining to relationships between Jews and the Gentile world that they inhabit. It is also studded with narrative, dialogue and homily: approximately 20 percent of the tractate belongs to at least one of these genres. The combination of legal and non-legal material in this tractate makes the tractate a perfect starting point for any discussion of the complex relationships the rabbis had with Others around them and the laws they shaped for dealing with them and their world.

Within the tractate there are three dialogue-stories between rabbis and Gentiles or between rabbis about Gentiles. These stories share various formal textual traits. First, they are dialogues. Second, they all begin with the verb sha'al, which in this context has the technical mean-

* Thanks are due to Sarit Kattan-Gribetz for the kind invitation to the workshop "Rabbis and Others in Conversation" at Princeton in 2009 and Moulie Vidas for his warm hospitality while I was there, and both for their generous and meticulous editing work. I am also grateful to Christine Hayes, who responded to this paper, and to Mira Balberg, Yair Furstenburg and especially Ishay Rosen-Zvi, who read the paper and furnished extensive notes and kind advice. Thoughtful advice and references also came from the anonymous reader, whom I thank as well. Hebrew texts are not quoted in this paper for editorial reasons. Translations are all my own and are based on MS Kaufman A50 for Mishnah and MS Vienna 40 for Tosefta. Other sources were quoted and studied according to their manuscripts. Critical editions were also consulted (and are referred to in the notes when necessary). The discerning reader is advised to consult these sources as well. With some exceptions, bibliography is updated to 2010 .

${ }^{1}$ Lev Rab. ed. Margulies, 481, according to MS London 340. 
ing of "posing a halakhic inquiry."2 That is, they are all etiological dialogues, as attested by the shared inquiry mipenei mah ("for what reason?" "in light of which factor?"). ${ }^{3}$

Each of these dialogues has been read extensively on its own, as if analyzing the dialogue in isolation was sufficient for understanding the "rabbinic" approach to the problem posed therein. ${ }^{4}$ The problems in the tractate that are worked out in the set of dialogues, however, are greater than those within each single dialogue. A comprehensive approach that attempts to pinpoint the function of the three dialogues as part of the larger tractate will, I believe, lead us to a deeper understanding of the tractate, or at least of some of the problems that it so artfully covers up. ${ }^{5}$

This paper is an attempt to understand the construction and redaction of this tractate through the study of these dialogue-stories and their context. ${ }^{6}$ It will demonstrate sensitivity to genre and aesthetics in exploring questions of higher criticism. Additionally, I explicate the role of the dialogues as a stylistic and rhetorical device in the shaping of tractate Avodah Zarah. This will be a three-fold process. First, I read the dialogues as "stories." $\mathrm{Next}$, I examine them in light of the collections of mishnayot into which they are embedded. Finally, I present a reevaluation of the place of these dialogues in the overall textual structure of the tractate.

${ }^{2}$ See e. g. t. Ber. 4:16, pace Saul Lieberman, Tosefta Zeraim (New York: Jewish Theological Seminary, 1956) 22 line 64. See also $t$. San. 7:7 and Ishay Rosen-Zvi, "The 'Protocol' of the Study House in Yavneh? A New Look at Tosefta Sanhedrin 7” (Heb.), Tarbiz 78 (2009) 447-477, esp. ch. 3.

3 This question is quite rare in the Mishnah (it appears sixteen times in MS Kaufmann) and appears in stories only here. (My use of the designation "stories" follows Moshe Simon-Shoshan, "Halacha Lema'aseh: Narrative and Legal Discourse in the Mishnah" [PhD diss., University of Pennsylvania, 2005].)

${ }^{4}$ For literature, see notes on each dialogue below.

5 Two prerequisites for such a study - textual criticism and a philological study were filled by David Rosenthal, "Mishnah Avodah Zarah: A Critical Edition and Introduction" (Heb.; PhD diss., Hebrew University of Jerusalem, 1980) [hereafter: Rosenthal, $A Z$ ].

${ }^{6}$ In this respect, it is a departure from Moshe Simon-Shoshan, "Halachah," 81-82, who does not wish to "impinge" on the source-critical debate: "The claim that on a literary-linguistic level, the Mishnah is composed of a diversity of genres and forms is not contingent on the question of whether the Mishnah is made up of different strata and diverse sources on the historical-philological level, or the extent to which these strata and sources were integrated in the editorial process." Indeed, it is not necessarily contingent, but in this case it is.

7 Simon-Shoshan's framework for regarding "narrative" as part of the warp and woof of almost every mishnaic text, and differentiating between various "levels" of narrativity in the text, is quite compelling. See esp.chs. 1 and 2 of his "Halachah." For a survey of those before him who introduced literary methods into the study of rabbinic literature, see his introduction, idem. 
David Rosenthal posited that what we know today as Mishnah Avodah Zarah consists of two separate compositions: chapters 1-4 are "tractate Avodah Zarah," which we shall discuss in this paper. This tractate has a typical homiletic ending at 4:8. Chapter $4: 9$ to the end of the tractate is a separate composition, which could be termed "tractate Libated Wine" (yeyn nesekh). The two tractates are distinct from one another in various stylistic points, in the focus of the latter specifically on Gentile wine as opposed to other food of the Gentiles, and in the names of the sages in the latter half, which are later than those in the first half. The second half also features more exempla than the first half. ${ }^{8}$ I find this theory of two separate compositions quite convincing, and this premise, though not without difficulties, is the basis of our current study.

\section{A. Mishnah Avodah Zarah 2:5}

The first dialogue in the tractate is a conversation between R. Ishmael and R. Joshua on the subject of Gentile cheese. ${ }^{9}$

R. Judah said: R. Ishmael asked R. Joshua when they were on the road, "Why did they forbid the cheese of Gentiles?"

He said: "Because they ferment it in the stomach of a carcass."

He said: "But the [prohibition of the] stomach of the burnt-offering is more severe than [that of] a stomach of a carcass,"

and they said: "A priest who is of "sound' mind slurps it raw," and the sages did not agree but said: "No benefit may be derived [from it], but it is not a sacrilege (ein nehenin ve-ein mo'alin)?"

They said to him: "Because they ferment it in the stomach of calves [dedicated to] idolatry."

He said: "If so, why did they not forbid benefit derived from it?"

He led him to a different matter.

He said: "Brother Ishmael, how do you read: for your love is better than wine (Song 1:2), in the masculine (dodekha) or in the feminine (dodayikh)?"

He said: "In the feminine."

He said: "It is not so, for his companion [i. e., the next verse] testifies, to the smell of your good oil (Song 1:3) [in the masculine, shemanekha]."10

$\mathrm{R}$. Ishmael seems to be asking an innocent question: why did the rabbis forbid the cheese of Gentiles? He receives no good answer. R. Joshua tries to explain that Gentile cheese is forbidden because it is fermented in the stomach of a carcass. However, the milk in the stomach of the

${ }^{8}$ Rosenthal, AZ, 1:261-263.

${ }^{9}$ A full apparatus of Mishnah variants may be found in Rosenthal, $A Z$. Brackets indicate notes by the author.

${ }^{10} \mathrm{~m}$. Avod. Zar. 2:5. 
carcass may be consumed, according to rabbinic halakhah. ${ }^{11}$ This is proved by $\mathrm{R}$. Ishmael with an inference from a similar case, in which the stomach of a burnt offering may be consumed: although the offering is forbidden more severely than a carcass, a priest passing by the offering burning on the altar may slurp fermented milk from its stomach. $\mathrm{R}$. Joshua then tries to argue that Gentile cheese is forbidden due to the laws of idolatry, but $\mathrm{R}$. Ishmael refutes this explanation by pointing out that benefit derived from the cheese is permitted, unlike all other derivatives of idolatry. R. Joshua gives up, and "leads" R. Ishmael to a different matter.

Shlomo Naeh has suggested that this conversation is no innocent exchange: R. Ishmael knows that there is no answer to his question; he asks it simply to make a theological statement about forbidden Gentile foods more generally. ${ }^{12} \mathrm{R}$. Joshua tries to use a formalistic framework of specific prohibitions to explain the reasoning behind every forbidden Gentile item. In the end, however, formalism makes way for theology - just as R. Ishmael planned. R. Ishmael forces R. Joshua to agree that formalistic distinctions have no place in deciding which foods are forbidden. Using the verse from the Song of Songs, and its allegorical interpretation, he reads "for your love is better than wine" to mean "the love of God is better than wine": the people of Israel love their God more than Gentile foods, wine and oil, and therefore do not partake of such Gentile foods. Though R. Joshua does not answer R. Ishmael's specific question about cheese, he offers a rationale for all forbidden Gentile foods as a unit. They were forbidden by the Jews, or the rabbis, because Jews (or rabbis) love God more than wine or oil. ${ }^{13}$ This, Naeh persuasively explains, is the precise meaning of "he led him to a different matter" (hissi'o ledevar aher), R. Joshua is questioning the premise of the

${ }^{11}$ See also m. Hul. 8:5 y. Avod. Zar. 2:7, 41c and b. Avod. Zar. 35a-b, as well as Christine E. Hayes, Between the Babylonian and Palestinian Talmuds: Accounting for Halakhic Difference in Selected Sugyot from Tractate Avodah Zarah (New York: Oxford University Press, 1996) 32-35.

12 Naeh, "Love," 428.

13 That Gentile foods are forbidden per se is a prevalent opinion in Second Temple literature. See, most recently, David C. Kraemer, Jewish Eating and Identity through the Ages (London: Routledge, 2007) 25-38. See also Christine Hayes, Gentile Impurities and Jewish Identities: Intermarriage and Conversion from the Bible to the Talmud (New York: Oxford University Press, 2002) 108, 138-144. Hayes contends that foods can either be prohibited due to Gentile impurity or due to the fact that the foods themselves contain a prohibited substance. This dichotomy seems a bit problematic: some foods (for example, the bread of the Gentiles or the oil of the Gentiles) can be forbidden because they belong to Gentiles, not because they are impure - and Gentiles, since they are impure, like those with genital influxes, can render food impure, but this does not necessarily make the food forbidden. 
question R. Ishmael is presenting: ask not, he says, why it is prohibited; it is prohibited, as are all other Gentile foods.

The story in the Mishnah, however, is situated in the midst of a sequence of mishnayot; an analysis of the exchange between R. Ishmael and R. Judah in its proper literary context will further illuminate its purpose within the tractate. The mishnayot into which this story is placed are arranged in descending order of severity, from the most severe prohibitions to the least severe ones:

1. These are items of Gentiles that are forbidden, and from which no benefit may be derived: [...]

Meat on its way into a temple of an idol is permitted;

and on the way out it is forbidden, for it is similar to the "offerings of the dead" (Ps. 106:25) - the words of R. Akiva.

Those who are on their way to worship [... ${ }^{14}$

2a. Wine belonging to a Jew that is stored in wineskins of Gentiles or their jugs is forbidden, and no benefit may be derived from it - the words of R. Meir;

the sages say, benefit may be derived from it.

2b. Muries ${ }^{15}$ and cheese bithuniake ${ }^{16}$ of Gentiles are forbidden, and no benefit may be derived from them - the words of R. Meir;

the sages say, benefit may be derived from them.

2c. Stones of grapes and grape skins of Gentiles are forbidden, and no benefit may be derived from them - the words of R. Meir;

the sages say, benefit may be derived from them.

The story of R. Ishmael and R. Joshua

3. These are items of Gentiles that are forbidden, but benefit may be derived from them: $[\ldots]$

4. These may be consumed: $[\ldots]$

14 The matter of "those who are on their way to worship" (tarafut) is an interpolation introduced here based on the stylistic similarity of that mishnah with the previous one. In both, those who are "going in" have one status (meat is permitted, worshippers forbidden), and on the "way out" the status is reversed (meat is forbidden, worshippers are permitted).

${ }^{15}$ Muries is a Latin loanword: "brine used for pickling" (Oxford Latin Dictionary, ed. G. M. Lee, [Oxford: Oxford University Press, 1968], 1147). Cf. Greek halmyois (cf. m. Shab. 14:2: hilme and Yerushalmi ad loc., which explains that this food can only be made by a professional). See Samuel Krauss, Griechishe und Lateinische Lehnwörter im Talmud, Midrasch und Targum (Berlin: S. Calvary, 1898-99) 329. See also Michael Sokoloff, A Dictionary of Jewish Palestinian Aramaic (2nd ed.; Ramat Gan and Baltimore: Bar Ilan University Press and Johns Hopkins University Press, 2006) 296. For the price of muries, see Daniel Sperber, Roman Palestine, 200-400: Money and Prices (Ramat Gan: Bar Ilan University Press, 1991) 133-138.

16 "Cheese bithyniake" is not a kind of cheese. Bithyniake is merely a Greek gloss on "cheese" that means "Bythinian." Just as "Asakalonia" means "onions (from Ascalon)," so "bithyniakê" means "cheese (from Bythina)." See Rosenthal, AZ, 258-259. It is also a gloss in t. Avod. Zar. 5:13 and t. Shevi. 5:9. In later sources, however, there is a distinction between cheese and "cheese bythiniake"; see b. Avod. Zar. 34b. 
There are four units in this collection. Unit 1 enumerates products from which no benefit may be derived. These include wine and wine products, as well as other by-products of idolatry ("hearted hides"). Unit 2 features products similar to those in unit 1 according to the opinion of R. Meir, but similar to those in unit 3 according to the sages. Unit 3 enumerates products that everyone agrees are forbidden but from which benefit may be derived. Unit 4 lists products that are permitted even for consumption. Without the dialogue, the division between units and the gradual easement of prohibitions from unit 1 to unit 4 would be obvious. The dialogue is inserted at the center point of the collection, and it does not fit into the neat structure of descending severity upon which the collection of mishnayot is based.

Following Naeh, I see this dialogue as ending on an emphatic note: formalistic distinctions are no impediment to the love of God that is manifest in the avoidance of Gentile food according to the laws in the Mishnah. ${ }^{17}$ If so, the conclusion of the dialogue, which contends that all Gentile foods are forbidden equally, is out of place in a collection of mishnayot that posits that some Gentile foods are in fact forbidden more than others. ${ }^{18}$ The prohibition of wine and oil, the two items cited by R. Joshua in the verse to which he is referring, are not identical: benefit derived from wine is forbidden, whereas benefit derived from oil is not. ${ }^{19}$ The mishnayot

17 This is not to say of course that the author of the dialogue does not know of such distinctions, as two of them come up in the course of the dialogue! The author, and R. Joshua, know of such distinctions but undermine and virtually delegitimize them.

${ }^{18}$ It is interesting, however, that R. Ishmael and R. Joshua both agree in their argument that benefit derived from cheese is not forbidden. This means that $\mathrm{R}$. Joshua's homiletical answer, appealing as it is, does not actually even fit the facts of the question.

19 On oil, see Rosenthal, AZ, 166-174; Zvi Aryeh Steinfeld, "Concerning the Prohibition Against Gentile Oil" (Heb.), Tarbiz 49 (1980) 264-77; Martin Goodman, "Kosher Olive Oil in Antiquity," in A Tribute to Géza Vermès: Essays on Jewish and Christian Literature and History, ed. P. R. Davies and R. T. White (New York: Continuum, 1990) 227-245; and recently, Jordan Rosenblum, "Kosher Olive Oil in Antiquity Reconsidered," JSJ 40 (2009) 356-365. Vermes sees the repeal of the decree on oil as the work of a confused halakhist; Rosenblum believes it is an economic enactment. Rosenblum calls the insertion of the emendation "Rabbi and his court allowed oil" an "editorial insertion" (p. 359). This is a terminological blunder, unless he means something like "copy-editor," someone reading a manuscript and inserting a gloss which is not part of the Mishnah at all. The gloss is attested in two different formulae; various MSS use different names - within these two formulae - for the authority who "allowed" the oil, and it is attested in different places within the Mishnah in various MSS, a clear sign of a late interpolation into a work. Moreover, in many good witnesses of the Mishnah there is no gloss (see Rosenthal, $A Z$, edition ad loc.). As Rosenthal has shown $(A Z, 166-174)$, the authority that permitted the oil is R. Judah Nesi'ah, Rabbi's grandson, who flourished around 260 or even 270 . The interpolation was not known by Rav and Samuel, meaning that it did not hark back to the circle of Rabbi. 
distinguish, for example, between Gentile milk that has been milked unsupervised and milk that was milked under supervision; between meat going into the house of an idol and meat coming out; and between wine and wine derivatives, from which benefit is forbidden, and all other products, which are simply not to be consumed. These distinctions make sense only in the context of discreet prohibitions, such as forbidden admixtures and idolatry, not in the context of a blanket prohibition on Gentile food. ${ }^{20}$

At the same time, of course, our mishnah offers a blanket justification for the prohibitions on Gentile foods. This justification is much stronger than the individual justifications apparent from the mishnayot in the collection. It is plausible that the dialogue was introduced to provide such a justification for the collection as a whole - according to the dialogue. But while the "theological" reasoning of the dialogue is more compelling, because it encompasses all the forbidden food-items and provides for the arbitrariness of the system (things are the way they are because they are the way they are), it also hangs on a thread, since it cannot be supported by any previously known system of food laws (such as kashrut or the prohibition on idolatry). The Talmudim, due to this exchange, are hard-pressed to find a good reason for the prohibition of cheese. ${ }^{21}$ The dialogue therefore offers a justification for the

${ }^{20}$ Naeh, "Love." This is precisely as Hayes contends (see n. 7 above); but Hayes's opinion is only one opinion that prevailed among the rabbis, and the dialogue presents a differing opinion. Jordan Rosenblum, Food and Identity in Early Rabbinic Judaism (Cambridge: Cambridge University Press, 2010) 83-90, attempts to explain these prohibitions on the ground of the identity of the party preparing the food. This would go well for milk, but not for "hearted hides" or meat going into the house of an idol. Additionally, I am not sure that the mere "supervision" of a Jew over a Gentile milking a goat constitutes a relationship of "chef" and "sous-chef" between them, as Rosenblum posits for cheese (ibid.).

${ }^{21}$ See y. Avod. Zar. 2:4-5, 41c for a multitude of reasons for this prohibition, none of which is especially convincing. The Bavli distinguished between cheese from Bythinia/ beit oniake (see n.9 above) and "regular" Gentile cheese, and discussed the latter on 35b. For subsequent controversies over Gentile food items, see Sefer hiluf minhagin bein benei eretz israel uvein benei bavel, ed. B. M. Levine (Jerusalem, 1942) and Hahilukim shebein anshe mizrah uvenei eretz israel, ed. M. Margulies (Jerusalem, 1938) $\$ 10$ (cheese and milk), 30 (bread), 53 (cooked food). (These are two editions of the same work, which enumerates a number of differences in ritual and practice between Babylonian and Palestinian Jews. Ed. Levine is a collection of citations, while ed. Margulies is a critical edition from manuscript material.) Pirqoi ben Bavoi chastised Palestinian Jews for their leniency over these matters. See Neal (Nahman) Danzig, "Between Palestine and Babylon: New Fragments of the Work 'Pirkoi ben Bavoi'” (Heb.), Shalem 8 (2008) 1-32 and Robert (Yerahmiel) Brody, Pirkoi ben Bavoi and the History of the Inter-Jewish Polemic (Tel Aviv: Tel Aviv University, 2003). See also the opinion of R. Jacob Tam (12th c.) in Teshuvot ufesakim, ed. Kupfer, 32 ("For myself, I permit the cheese of Gentiles") and the various opinions presented in Tosafot, Avod. Zar. 35a, s. v. "hada." 
prohibition on all Gentile foods, but it does not fit with the thrust of the collection of mishnayot that it is meant to justify.

\section{B. Mishnah Avodah Zarah 3:4}

The second dialogue in the tractate recounts an exchange set in a bathhouse in Akko. ${ }^{22}$

Paraklos b. Plaslos asked Rabban Gamaliel in Akko, as ${ }^{23}$ he was bathing in the bath of Aphrodite.

He said, "It is written in your Torah, none of the herem ${ }^{24}$ shall cling to your hands (Deut 13:18); why then do you bathe in the bath of Aphrodite?"

He said, "Answers are not given in the bath."

And when he left, he told him, "I did not come into her precinct (gevulah), she came into my precinct. They do not say, let us make a bath a decoration for Aphrodite, but Aphrodite is made a decoration for the bath. Another thing: were they to give you much money, would you come to your idol naked and impure of seminal emission, and urinate in front of her? This one stands on the sewer, and all the people urinate in front of her. It says their gods (Deut 12:2). That which is treated like a god is forbidden, and that which is not treated like a god is permitted." 25

Paraklos ${ }^{26}$ and R. Gamaliel were bathing together in Aphrodite's bath in Akko. The former, deridingly nicknamed "ben Plaslos" or "bean-

22 This dialogue has been the subject of extensive discussion and debate. See, most recently, Ishay Rosen-Zvi, "Shall You Destroy All the High Places?" (Heb.), Reshit 1 (2009) 91-116. See also Azzan Yadin, "Rabban Gamaliel, Aphrodite's Bath, and the Question of Pagan Monotheism," JQR 96 (2006) 149-179; Emanuel Friedheim, "The Story of Rabban Gamaliel in the Bath of Aphrodite in Acre: A Study of Palestinian Realia" (Heb.), Kathedra 105 (2003) 7-32; Yaron Zvi Eliav, "The Roman Bath as a Jewish Institution: Another Look at the Encounter Between Judaism and the GrecoRoman Culture," JSJ 31 (2000) 416-454; Seth Schwartz, "Gamaliel in Aphrodite's Bath: Palestinian Judaism and Urban Culture in the Third and Fourth Centuries," in The Talmud Yerushalmi and Graeco-Roman Culture 1, ed. P. Schäfer (Tübingen: Mohr Siebeck, 1998) 203-217; and Moshe Halbertal, "Coexisting with the Enemy: Jews and Pagans in the Mishnah," in Tolerance and Intolerance in Early Judaism and Christianity, ed. G. Stanton and G. Stroumsa (New York: Cambridge University Press, 1998).

23 "As," meaning both "while" and "since," to reflect the ambiguity of the Hebrew.

24 Herem is a term pregnant with many strata of meaning and context, and therefore I leave it untranslated. See J. A. Naudé, herem, New International Dictionary of Old Testament Theology and Exegesis (Grand Rapids, Mich.: Zondervan, 1997) 2.276-277. See also William Horbury, "Extirpation and Excommunication," VT 35 (1985) 13-38. 25 m. Avod. Zar. 3:4.

26 This is the vocalization in MS Kaufman; MS Parma 3173 (De Rossi 138) is not vocalized here, but the spelling there reflects a similar vocalization. See Rosenthal, $A Z$, edition ad loc. for variants. 
man," 27 asks R. Gamaliel why he is deriving benefit from the bath of Aphrodite. Your Torah, says Paraklos, explicitly forbids benefit derived from idols, for the verse says "and none of the condemned things shall cling to your hand" (Deut 13:18). ${ }^{28}$ Four alternative answers are provided in the name of R. Gamaliel:

1. Answers are not given in/on the bath.

2. I did not come into her limits.

3. They do not say, "Let us make a bath for Aphrodite."

4. The idol is permitted, for this is not how a god is treated.

First, note that the answers shift from the bath to the goddess. The answer "we do not give answers in/on the bath" can be interpreted as "perhaps we should not be having this discussion at all." 29 Then R. Gamaliel addresses the area around the goddess, her precinct, templum or perhaps temenos. ${ }^{30}$ The following answer focuses on the building at the center of the sacred precinct (temple/bath). The final answer, the linchpin of the entire dialogue, focuses on the idol itself and the mode

27 Yadin, "Question," prefers the reading Plosfos, attested in the Babylonian witnesses of the Mishnah, because there is no "Plaslos" in the Greek onomasticon (per Avraham [Adi] Wasserstein, "Rabban Gamaliel and Proclus of Naucratis" (Heb.), Zion 45 [1980] 257-267). Dov Zlotnick, "Proklos ben Plaslos" (Heb.), in Saul Lieberman Memorial Volume, ed. S. Friedman et al. (Jerusalem and New York: Jewish Theological Seminary, 1993) 49-52, points out that plaslos is the Yellow Lupin (Lupinus Luteus); see m. Kil. 1:3 and t. Kil. 1:2, as well as Yehuda Feliks, Plants and Animals of the Mishnah (Heb.; Jerusalem: Institute for Mishnah Research, 1985) 124.

${ }^{28}$ Rosen-Zvi, "High Places," points out that Paraklos is using the rabbinic interpretation of Deut 13:18 in his question, which understands the verse as referring to a prohibition on idols and benefit derived from them, not an obligation to destroy them, as is inherent in the term herem. This, explains Rosen-Zvi, frames the discussion from its very inception in terms of prohibition. According to the verse he quotes, Paraklos could well have asked why Gamaliel does not ransack the bathhouse, but he does not, and this choice is significant.

${ }^{29}$ As the anonymous reader of this article suggested, this may be read as an anticipation of R. Gamaliel's final response: bathhouses are not suitable arenas for religious engagement - neither R. Gamaliel's religion, nor that of his interlocutor (see also below, n 34.)

30 On temenos and its significance in Hellenistic worship, see Walter Burkert, "The Meaning and Function of the Temple in Classical Greece," in Temple in Society, ed. M. V. Fox (Missoula: Eisenbrauns, 1988) 29-48, and Christine Survinou-Inwood, "Early Sanctuaries, the Eighth Century and Ritual Space: Fragments of Discourse," in Greek Sanctuaries: New Approaches, ed. N. Marinatos and R. Hägg (London: Routledge, 1993) 1-17, esp. 4 ff. Eliav, "Bath," claims that the point of the answer is not "she came into my limits," but rather the beginning "I did not come into her limits," claiming in essence that Gamaliel did not enter the sacred precinct. But then what does one do with the end of the sentence? It seems that the answers are mere polemic, and "I was here first," though not sound halakhic reasoning, is a passably good retort. See also Yadin, "Question," 170. 
in which it is treated by its visitors. Second, we see that none of these replies is satisfactory at all. The first one is not even much of an answer - it is an avoidance of the question. The other three answers make no sense: although the ritual status of the bath in Roman religion is a point of contention, ${ }^{31}$ this bath was made for Aphrodite, and R. Gamaliel did indeed come into her precinct: it was, after all, "the bath of Aphrodite." As the Bavli already points out, if the bath was made for Aphrodite, then that is how the god is worshipped. ${ }^{32}$ Indeed, the Talmudim do not hold these answers in high regard. ${ }^{33}$

The Tosefta contains perhaps the first attempt to bring R. Gamaliel's homily in line with the rest of the Mishnah, by using it as a justification for the laws of nullification.

And could all idols nullified by Gentiles be forbidden? Scripture says, the statues of their gods (Deut 12:3) - those that are treated like God are forbidden, and those which are not treated like God are permitted. And could

${ }^{31}$ See Friedheim, "Bath," and Yaron Zvi Eliav, "On Avodah Zarah in the Roman Bath - Two Notes" (Heb.), Kathedra 110 (2003) 173-180, esp. n. 10. Eliav's contention on p. 180 that the bath was "public" is conjectural. See also Shelley Hales, "Aphrodite and Dionysus: Greek Role Models for Roman Homes?" in Role Models in the Roman World: Identity and Assimilation, ed. S. Bell and I. L. Hansen (Ann Arbor: University of Michigan Press, 2008) 235-255. Compare this to Halbertal's contention ("Coexisting," p. 166) that R. Gamaliel is attempting to describe the bath as neutral space, so as not to allow idolatry to claim what is in his mind rightfully his, as part of the public sphere (note also that if the first reply of R. Gamaliel does indeed prefigure the last reply, then he is marking the bath as off-limits to all religions, making it completely neutral). Eliav, ibid., points to flaws in Halbertal's "neutrality doctrine," as does Beth Berkowitz, "The Limits of 'Their Laws': Ancient Rabbinic Controversies about Jewishness (and Non-Jewishness)," JQR 99 (2009) 121-157. Berkowitz points out that it was the school of R. Akiva that attempted to create neutral spaces, while the school of R. Ishmael was more suspicious of this tendency. Even the school of R. Akiva, however, would be hard pressed to call the bath of Aphrodite a "neutral space." Berkowitz also makes important observations on the problems inherent in assuming the rabbis - or any other ancient intellectual group - even had a concept of "neutrality" in their world; see pp. $155-157$.

32 As stated by $m$. San. 7:6, and perhaps significantly nowhere in m. Avod. Zar: "He who defecates (po'er 'atzmo) before Baal Peor [is liable], for such is his worship. He who throws a stone at Mercurius [is liable], for such is his worship." Mercury-Hermes was indeed worshipped by stone-throwing (as suggested by the very name Hermes, meaning "of the heap [of stones]"); see W. K. C. Guthrie, The Greeks and Their Gods (Boston: Beacon, 1954) 88 and n. 5. Baal Peor, however, had nothing to do with the sort of worship attributed to him (see K. Spronk, "Baal of Peor," in Dictionary of Deities and Demons in the Bible, ed. K. van der Toorn et al. [Leiden: Brill, 1995] 147), and the attribution seems to be a folk etymology for an obscure name of an unknown god. See also the cycle of tales regarding Baal Peor in Sifre Num 131.

33 y. Avod. Zar. 3:4, 42d calls the answer "distracting" (hefleg); b. Avod. Zar. 44b calls it "stolen" (genuvah); the Bavli picks the dialogue apart from every possible direction. 
the idol of Israel nullified by a Gentile be permitted? Scripture says, the statues of their gods - only their gods, those which are treated like God are prohibited and those which are not treated like God are permitted, and those of Israel, whether or not they are treated like God, are prohibited. ${ }^{34}$

The Tosefta attempts to use R. Gamaliel's homily in order to ground the laws of nullification in scripture. ${ }^{35}$ However, R. Gamaliel's homily in the Mishnah is not a justification for these laws at all! Nullification of an idol must entail at least the semblance of a physical action directed at an idol, not just bathing by it - which is an accepted use of an idol, as we have shown.

Even if R. Gamaliel is trying to ignore these realities and posit a law that states that if idols are to create forbidden spaces around themselves they must be treated "like gods" (i. e., in a manner that R. Gamaliel would deem fit for a god), this law is contradicted by other parts of the Mishnah. The Bavli is quick to point out that $m$. Avod. Zar. 4:3 rules that an idol with a garden or a bathhouse prohibits benefit from the garden or bathhouse "for profit" (betovah), while benefit "not for profit" (shelo betovah) is permitted. The term betovah implies a price paid, in money, goods, services or simply a returned favor, for the use of the bath. This is a clear criterion for deciding when one may or may not use a bathhouse belonging to an idol, regardless of the unseemly actions that go on there.

Additionally, m. Avod. Zar. 1:7 decrees that bathhouses may be built with Gentiles until the dome that holds the statue is erected, implying that the statue in the dome is indeed an idol, whose presence in the dome makes it forbidden, contrary to R. Gamaliel's contention. ${ }^{36}$ R. Gamaliel makes no mention of either law, and his distinctions are disregarded by those sources. ${ }^{37}$

${ }^{34}$ t. Avod. Zar. 6:6. In MS Erfurt, "of Israel" in line 5 is missing but is implied by the end of the text. MS Erfurt also reads leshum eloah in place of minhag eloah, translated here "like God." The meaning is the same for our purposes.

35 On these laws and their supposed basis in scripture (or lack thereof), see Noam Zohar, "Avodah Zarah and Its Annulment" (Heb.), Sidra 17 (2002) 63-77, esp. 63-66. See also the discussion of the term and meaning of the laws of annulment below.

36 As noticed by Halbertal, "Coexisting," 167, this is an additional attempt to distinguish building and idol, which should not necessarily be distinguished or even distinguishable from each other.

37 Various distinctions could be made between these mishnayot (for 1:7 more easily than for 4:3), but they would mostly be artificial, scholastic attempts at resolving the manifest incongruity between treating the bathhouse in a formalistic manner and taking it to the realm of the theological. 
Moreover, not only are the answers not congruent with the laws regarding bathhouses in the rest of the tractate, but they are also decidedly out of place in their literary context. The collection of mishnayot regarding images is constructed as an exegesis of Deut 7:25-26. ${ }^{38}$ Scholars have long noticed that the Mishnah replaced the commandment to destroy idols with a prohibition on their use. ${ }^{39}$ This replacement was not just legislative. ${ }^{40}$ As can be seen in a comparison of the verses and the collection of mishnayot beginning "All images" (3:1), it was exegetical as well:

38 The phenomenon of midrash hidden in the Mishnah, following verses and expounding on them, while making no explicit mention of this fact, is quite prevalent in the Mishnah, and has received no proper scholarly treatment to date (see, e. g., Rosen-Zvi, "Protocol," ch.4). It is distinct from whole midrashic units woven into the Mishnah (e.g., San. 2:3), as well as from single verses explicitly quoted in the Mishnah.

39 This was, in fact, a point of contention among Tannaim. As pointed out by Rosen-Zvi, "High Places," the school of R. Ishmael did not accept this change and continued to hold to the original obligation to destroy the idols literally (taking into account, of course, pragmatic considerations). The first to discuss this revolution was Efraim E. Urbach, "The Laws of Idolatry and Archaeological and Historical Reality in the Second and Third Centuries" (Heb.), in From the World of the Sages, ed. idem (Jerusalem: Magnes, 1988) 125-178, who explained these rabbinic leniencies as part of an attempt to adapt to changing economic conditions in the Roman Near East after the destruction (pp. 134-136), as well as a realization that both Jews and Gentiles were not all that serious about the powers attributed to the gods (p. 155). His position was problematized by Hayes, Talmuds, 57-63, and Seth Schwartz, Imperialism and Jewish society, 200 B. C. E. to 640 C. E. (Princeton: Princeton University Press, 2001) 172-177 (their critiques hold true for Rosenblum, "Oil," as well). Schwartz, however, fails to provide a compelling explanation for this change, especially in light of the Ishmaelian position (to which he does not refer), which abrogates the obligation to destroy idols as a matter of expediency, not ideology. Yair Furstenberg reads this revolution in the context of Greco-Roman religion, especially civic religion, in the Roman Near East; see Furstenberg, "Nullification of Idols: The Rabbis' Dialogue with Idolatry under the Roman Empire" (Heb.), Reshit 1 (2009) 117-144. Ishay Rosen-Zvi, "High Places" contends that $m$. Avod. Zar. 3:3, which rules that vessels found with the shape of the sun, moon or dragon should be "taken to the Dead Sea," is an Ishmaelian opinion which does not abrogate destruction of idols entirely. I do not believe this reading is the only correct one, and the term "taken to the Dead Sea" is purposely ambiguous. Cf. the other occurrences of the term in the Tannaitic corpus that all rule about monies obtained in problematic circumstances (e. g., m. Naz. 4:4, 4:6; m. Avod. Zar. 3:9). The ruling could be referring to use of the vessels, which is prohibited and thus there is nothing left to do with them except destroy them. The sages object to R. Jose's ruling that other forms of destruction may be used, since benefit can be derived from that destruction as well ("it, too, can become fertilizer"), implying that benefit from the idolatrous vessel and its use are the locus of the prohibition, not its mere existence.

${ }^{40}$ The verse is expounded neither in Sifre Deut., nor in the remaining fragments of Mek. Deut., as it is outside the scope of both works. 


Torah Mishnah

(Deut 7:25a) You shall burn the statues of their gods in fire.

\section{(Deut 7: 25b)}

You shall not covet the silver and gold on them, and take them for yourself, lest you stumble upon it, for it is the abomination of the Lord your God.

(Deut 7:26a) And you shall not bring an abomination into your home and become herem like it.

(Deut 7:26b) You shall entirely abhor and detest it
(3:1) All images are prohibited, for they are worshipped once a year - the words of R. Meir.

The sages say: None are prohibited unless they hold a staff or a bird or a ball. R. Shimon b. Gamaliel says: Anything that holds anything [is prohibited]. (3:2) He who finds broken images, they are permitted. If he finds the shape of an arm or leg, they are forbidden, for similar [objects] are worshipped.

(3:3) He who finds vessels with the shape of the sun or the moon or a dragon should take them to the Dead Sea.

R. Shimon b. Gamaliel says: [Images] on the dignified [vessels] are forbidden; on the common [vessels] are permitted. R. Jose says: He can file them and scatter [the dust] to the wind, or throw [the vessel] into the sea. They told him: it, too, can become fertilizer, for it says and none of the condemned should cling to your hand (Deut 13:18).

(3:3) [story of R. Gamaliel in the bath] (3:4) Gentiles who worship mountains and hills: they are permitted, and what is on them is forbidden. For it says: You shall not covet the silver and gold on them, and take them (Deut 7:25). R. Jose the Gallielan says [...] R. Akiva says $[\ldots]$

(3:5) One whose home was adjacent to the home of an idol, and [the house of the former] fell, he may not rebuild it. What should he do? [...]

If the wall was jointly his and the idol's, [half is forbidden, and half is permitted].

Its stones, wooden beams, and rubble carry the impurity of a crawling thing, for it says: Entirely abhor them.

The Mishnah expounds the verse carefully: the images of the gods are forbidden ("burn the statues of their gods in fire," 3:1-3), while natural 
phenomena are permitted ("do not covet the gold and silver on them," 3:5). "Br "Bring no abomination into your home" is the basis for a discussion on the matter of a person who was unlucky enough to share a collapsed wall with a temple (3:6). "Entirely abhor them" is read as meaning that idols and idolatry impart impurity like a crawling thing. ${ }^{43}$ The exchange in m. Avod. Zar. 3:4, specifically R. Gamaliel's last answer, introduces a new criterion that modifies this entire system and makes it much more lenient. Idols, actual statues of gods, must be treated like gods in order to be subject to any sort of prohibition - all the more so vessels with images. ${ }^{44}$ This criterion is an exegesis of the words "their gods" in the verse, and R. Gamaliel says so explicitly. ${ }^{45}$ This exegesis also breaks the homiletical sequence of the Mishnah and re-reads, out of place, two words in the phrase it has already read.

These connections to the immediate context are somewhat weakened by the fact that the story offers a criterion for leniency unheard of in the entire tractate, and in doing so significantly modifies the laws of idolatry (in a manner subsequently adopted, in a modified form, by Gamaliel's son, and in another modified form by the Tosefta, Avod. Zar. 6:6, discussed above).

${ }^{41}$ Since the first part of the verse forbade idols, the part that forbids coveting the gold and silver on them must be about idols that are not forbidden, i. e., natural phenomena that are worshipped, such as mountains or hills. The mention of mountains and hills is a reference to Deut 12:2, which is also the subject of the debate between R. Akiva and R. Jose Haglili, paralleled in Sifre ad loc.

42 This exegesis seems to be an instance of hakkatuv meddaber. For this mode of exegesis, see Azzan Yadin, Scripture as Logos: Rabbi Ishmael and the Origins of Midrash (Philadelphia: University of Pennsylvania Press, 2001) 23-24.

43 Shaketz (translated "abhor") is associated with crawling things and their impurity, using Lev 7:21. Sheketz and sheretz are interchangeable. See BDB, שרץ, שv, 1056, 1054. R. Akiva's dictum appears also in m. Shab. 9:1, Mek. Deut. 12:3 and t. Avod. Zar. $5: 6$. The original context of the dictum is difficult to ascertain, but it seems that it is in Mishnah Shabbat. See also Noam Zohar, "Rabbi Akiva Said': The Incorporation of a 'Foreign' Collection in the Redaction of the Mishnah" (Heb.), Tarbiz 70 (2001) $353-$ 366.

44 This criterion is also mentioned in the previous mishnah by R. Gamaliel's son, R. Shimon b. Gamaliel, but not about idols per se, only about vessels with images that may or may not have been worshipped. Other criteria mentioned in the mishnah are also exegeses of the words their gods: "all images are forbidden for they are worshipped" (R. Meir); "none are prohibited unless they hold a staff, or a bird, or a ball" (the sages; these are symbols of dominion and thus typical of the emperor cult, as pointed out by Urbach, "Idolatry"). Broken images are prohibited, for they are not gods, but if they are worshipped they may be gods, etc.

${ }^{45}$ Our findings significantly corroborate Yadin's contention in "Question," 167: "Nor should Rabban Gamaliel be automatically understood as a representative of "the rabbis."' Yadin's prosopographical evidence is now supported by internal and structural findings within the tractate itself. 


\section{Mishnah Avodah Zarah 4:7}

The third dialogue in the tractate is more philosophical in nature, and it inquires as to God's role in confronting idolatry. Understanding this dialogue requires some more background information about the conceptual framework of tractate Avodah Zarah and its way of interpreting and developing biblical law.

In rabbinic parlance, avodah zarah means "idol worship," rather than "foreign worship." 46 Worship of idols in the tractate is usually centered on statues (called tzelem, "image," or tzurah, "figure"), sometimes associated with a temple (bayit shel avodah zarah) or a grove (asherah, avodah zarah she-haytah lah ginah). ${ }^{47}$ Nature is not usually an object of worship. ${ }^{48}$ When someone finds images of the sun or moon on a vessel, the vessel is prohibited because of the image, not because of its connection with a sun or moon cult (i. e., if the vessel had "sun" or "moon" written on it, it would not be prohibited).

Moreover, as mentioned above, the biblical imperative to destroy idols has all but disappeared in the Mishnah. ${ }^{49}$ The verses associated with the destruction of idols have been reinterpreted to mean that idols and the objects associated with them are prohibited. This prohibition may be circumvented by use of a procedure called bitul ("nullification"), in which a Gentile creates a minor defect in the cultic object, signifying that it is no longer a god. ${ }^{50}$ Noam Zohar contends that bitul is an essen-

46 See Zohar, "Avodah Zarah": 63-66.

47 As is typical of Greco-Roman gods. See above, n. 32.

48 Indeed, the only instance of nature-worship in the tractate is used as an illustration for the fact that idolizing nature does not prohibit it (3:5); even that instance is probably a homily on Deut 12:2 or 7:25. See the discussion above, Section B.

49 See above, n. 15.

${ }^{50}$ Bitul is an Aramaism that crept into later strata of biblical Hebrew (Eccl 12:3), and its basic meaning in both Hebrew and Aramaic is "to be idle." It is cognate with

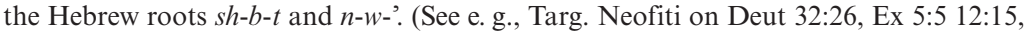
Lev 2:3 and 26:6.) In one case, the rabbis differentiated between the two: In the context of hametz, biblical sh-b-t (in Ex 12:15) was read as an obligation to destroy (see Mek. $R S$, ed. Epstein-Melamed, 17: "tashbitu - by means of burning"). Bitul, however, was read as a mental process, as in $m$. Pes. 3:7: "If one is on the way to slaughter his paschal offering [...] and remembers that he has hametz in his home, if he is able to return [home] and burn [the hametz] and return to the mitzvah, he should. And if not, he should nullify it in his heart (mevatelo belibbo)." This mishnah explicitly juxtaposes bicur (i. e., hashbatah) with bitul: the former is a physical process, the latter mental. It is not unreasonable that bitul was then transplanted to the arena of Avodah Zarah in which mental invalidation was required. Notice, for example, that the rabbis' opinion of how to dispose of hametz is echoed by R. Jose in m. Avod. Zar. 3:3, the only mishnah that details a method for ridding oneself of idols. There are other instances of bitul in 
tially psychological procedure and that the Gentile, in breaking a piece of the idol, essentially forswears the god. ${ }^{51}$ This forswearing is what causes the prohibition to cease. ${ }^{52}$ Yair Furstenburg, however, has pointed out several striking parallels between bitul and damnatio memoriae, destruction meted out on images of Roman emperors who fell out of favor with the Senate and the people. Damnatio is a physical action, a political process played out on the terrain of the images of the emperor. ${ }^{53}$ In the same way, mere forswearing has no effect in the Mishnah: even defiling the idol with excrement or urine has no power to affect bitul, still less just talking at it or about it. ${ }^{54}$ Additionally, Furstenburg claims, just as damnatio is the result of a consultation between a new emperor and the Senate (as a representative of the people), bitul cannot be enacted by Jews (n. 76), but only by Gentiles, as they are the ones who are replacing their old gods with the new God.

Against this background, situated at the end of the segment in the Mishnah that discusses nullification, Gentiles ask the elders in Rome why God does not effect bitul on all the idols in the world. The dialogue that ensues is quite curious:

They asked the elders in Rome. "If He does not will idolatry to exist, why does he not annul it?"

They said: "If they worshipped something the world does not need, he would have annulled it. But behold, they worship the sun, and the moon, and the stars. Would he destroy his world on account of the mindless?" They said: "If so, he can destroy what the world does not need, and keep what the world needs." They said: "Then we too strengthen the hands of the worshippers of the latter, for they will say, know that they are gods, for they have not been annulled." 55

the Mishnah, but they are closer to the original meaning, cognate with hashbatah, and always appear with actions or rites: see Zohar, "Avodah Zarah," 70 and n. 24. Zohar does not connect bitul hametz with the same action as applied to idols and explains the bitul of idols as "legal nullification," but this definition is not satisfactory, especially for his purposes. Zohar's claim that idols must be nullified by a mental action that is tantamount to destruction is better fortified by a connection between bitul hametz and bitul avodah zarah.

51 Zohar, "Avodah Zarah."

52 Zohar contends that the Yerushalmi's ruling that a Gentile may be compelled to nullify an idol is "ungrounded in Tannaitic sources"; see his "Avodah Zarah," 74 n. 40.

53 Furstenberg, "Nullification."

54 Rabbi (in MS Munich 95, R. Eliezer) holds that selling the idol, however, does effect bitul - but this is a minority opinion. However, if held, it would mean that Jews could have unfettered access to the housewares market and buy any and all vessels they wished to buy, whether with images or without. Cf. m. Avod. Zar. 3:3.

55 m. Avod. Zar. 4:7. 
The elders are asked why God does not nullify all the idols in the world; they reply that if God were to effect bitul on all the foreign worship in the world, he would destroy it. This is a play on words, and a puzzling one at that. Bitul has a technical meaning: causing an idol to lose its prohibited status. But it also has a more simple meaning: to cause something to cease its action, or cease to exist. ${ }^{56}$ The inquirers could be asking about the technical meaning, and this is what the reader/listener expects, after a discussion of the particulars of nullification. The elders in the dialogue, however, understand it in the less technical manner and equate it with "destruction." Indeed, their consternation at the mere possibility also reflects a view that the entire world is an object of the cult, a view not prevalent in the rest of the Mishnah. The rabbis are retreating to a more biblical picture of the laws of idolatry, in which nature is the object of the cult, and the law for dealing with it mandates that it be destroyed. They even translate "nullify" with the biblical term "destroy" (ye'abed), borrowed from Deut 12:2. The exchange in the dialogue plays on this dual meaning. To paraphrase: In context the question means "why does God not effect nullification on all the idols in the world?" But the rabbis understand it as meaning "if God does not will other worship to exist, why does he not destroy the cults?"

The dialogue itself may not be employing this wordplay at all: it might be a skilled redactor who took a dialogue that existed in a similar form elsewhere and wove it into the series of mishnayot that discuss nullification of idols, ${ }^{57}$ perhaps to provide a homiletic ending to the tractate.

The dialogue stands at odds with the surrounding mishnayot, both regarding the meaning of the term bitul and also in the reality it depicts, portraying idols as focused on nature worship, not on image worship. The shadow of doubt the dialogue casts on the entire enterprise of bitul is quite striking. In the hands of God, bitul means something else entirely, and the mishnaic bitul is not good enough for God. Indeed, while the laws of nullification provide an adequate substitute for the obligation to destroy idols and idolatry, the dialogue says that the only way to really "solve" the problem of idolatry is to destroy the world, and a piecemeal solution is not possible. As this is not desirable, idolatry is

56 See above, n. 17.

57 See parallels in Mek. RI Bahodesh 6 (ed. Horowitz-Rabin, 226) and t. Avod. Zar. 7:7. The ending, however, is not in any of the parallels ("They said: If so, he can destroy what the world does not need, and keep what the world needs. They said: Then we too strengthen the hands of the worshippers of the latter, for they will say, Know that they are Gods, for they have not been annulled"). See Furstenburg, "Nullification." 
portrayed not as a temporary reality, but rather as inherent in the very existence of the world. ${ }^{58}$

\section{Summary}

The three dialogues in Mishnah Avodah Zarah are very much at odds with their surroundings. They undermine and cast doubts on all the laws around them. They are placed at strategic focal points inside a collection of mishnayot - either in their center, as is the case with the first two dialogues, or at their end, as with the last one. I have argued that these collections of mishnayot are independent of the dialogues and have an internal structure of their own. Each one of these dialogues is a "foreign body" within the collections, added to already formed and shaped collections of mishnayot at a later date, perhaps as part of the redaction process of "Rabbi's Mishnah" itself.

As pointed out at the beginning of this paper, the dialogues share certain formal traits: they are about justifications, and contain questions and answers. The reasons given are not good and must be backed up by additional reasons. There is a narrative twist in each of the stories. ${ }^{59}$ The realm of the divine is invoked in each to justify discrepancies between conception and practice (of Jews, of R. Gamaliel, and of God).

The dialogues are obviously at odds with their immediate context, but they were not interpolated by mistake: they are in dialogue with the mishnayot around them. They are formally connected to the mishnayot that precede and follow them, and engage with the subject matter. They are not transferred from elsewhere. It is more plausible that they are there for a reason.

This reason is probably a justification for the laws and the reality these laws react to, together with a certain concession that these justifications are neither self-evident nor very convincing. The dialogue about cheese attempts to explain a law that has no explanation, and in doing so ends up almost undermining the entire hierarchy of Gentile foods in

58 This position should be compared and contrasted with the position of the Ishmaelian Mekhilta to Deuteronomy on Deut 12:2. See Midrash Tannaim ad loc.; Solomon Schechter, "Geniza Fragments," JQR 16 (1904) 425-452, 776-777; and the new reading by Menahem Kahana, Geniza Fragments of the Halachic Midrashim (Heb.; Jerusalem: Magnes, 2005), frags. [12] and [13].

59 These formal traits, and the narrative twist, bring to mind the Greco-Roman chria; see Harry A. Fischel, "Story and History: Observations on Greco-Roman Rhetoric and Pharasaism," in Essays in Greco-Roman and Related Talmudic Literature, ed. H. A. Fischel (New York: Ktav, 1977). 
the Mishnah. The dialogue about the bathhouse has formal connections to the mishnayot around it, but undermines the system of prohibitions of idolatry in the Mishnah and lays out a different criterion, which is later only partially adopted by other Tannaim. ${ }^{60}$ The dialogue about the teleological significance of God's patience towards idols has the potential to make all the newly-formed laws of nullification of idolatry into a farce, because in the eyes of God, "nullification" is still simply "destruction."

All three dialogues, therefore, point out real problems in the rabbinic laws of idolatry. They try to "solve" these problems by subverting the question, but in doing so they end up calling attention to discomfort the rabbis may have felt with their own laws, as well as the strategies they used in facing this discomfort. The innovations the Mishnah introduced into the laws of idolatry are far-reaching: a prohibition on use and benefit supplanted the obligation to destroy idols. Nullification of idols was introduced. The food of the Gentiles, entirely taboo in the Second Temple period, was subjected to categorization and rationalization that connected it to other prohibitions more grounded in scripture. There was a movement towards more leniency in the use of the urban arena, full of statues and images as it may have been. All of these innovations are apparent from the laws of the Mishnah, not the dialogues. The reasons for these sea changes are not part of the scope of this paper and have been debated by scholars for many years, but the rabbinic reaction to them was apparently not unequivocal. The changes in the laws of idolatry required good explanations, which the redactors of the Mishnah did not want to give outright.

However, these dialogues have an additional purpose. As we have shown, they stand apart from the collections of mishnayot around them, but they are connected to them by certain traits of form and content. They are also connected to each other by virtue of their formal

${ }^{60} \mathrm{I}$ would add that it knows full well that it is advancing an innovative and problematic claim: it is attributing a question that should be dealt with seriously to a Gentile with a funny name ("bean man") and gives four answers that are more rhetorical than substantive. This is comparable to those matters that are marked by the rabbis as being the advice of the yetzer; see below, section E, as well as Moshe Weinfeld, "Things About Which Satan/the Evil yetzer/the Nations of the World Retort," Atara Lehayyim, ed. D. Boyarin et al. (Jerusalem: Magnes, 2000) 105-111. This is, however, not a case of the "true" answer being concealed by the rabbi and then revealed to his students, as discussed in Jenny Labendz, "Socratic Torah: Non-Jews in Rabbinic Intellectual Culture" (PhD diss., Jewish Theological Seminary, 2010). In stories such as those read by Labendz there is always a prooftext waiting to be presented to the students, whereas in this story it is presented to the interlocutor. Rabban Gamaliel does not appear to be leading Paraklos on, lying to him, or trying to teach him anything at all. This dialogue is therefore not an instance of "Socratic Torah." 
traits. Together they form a stylistic device that accompanies the learner throughout the tractate, bringing forth a message that is not necessarily the one that comes across from the rest of the tractate, or at least not as strongly.

The laws in Mishnah Avodah Zarah expend much effort towards two conflicting ends. The first is setting Jews and Gentiles apart. Jews should stay away from various items of Gentiles and Gentiles themselves in certain cases. The second is allowing Jews to traverse the idolatrous public arena by limiting the scope of what an "idol" is and allowing for the nullification of the idol. The rabbis (of the school of R. Akiva) decided that one need not destroy idols as a matter of obligation, but just keep away from them. ${ }^{61}$ However, the laws separating Jews from Gentiles were not only maintained, but cemented and explained in ways that firmly portray the Gentile as a demonized Other to the Jew. ${ }^{62}$ Our dialogues form a sort of "redactorial backbone" for the tractate and radicalize both rabbinic revolutions. On the one hand, they do away with any need to explain and ground the prohibitions of certain Gentile foods in previously known laws. They claim a theological origin for these prohibitions and link abstention from Gentile cheese (or wine or oil) to the love of God, no less - against the thrust of the collection of mishnayot about Gentile food. On the other hand, the second dialogue contracts and explains the laws concerning contact with idolatry to a point that one would be hard-pressed to actually transgress them without engaging in a formal act of worship as defined by the Mishnah. The third dialogue explains that the existence of idols is actually a logical imperative and that God cannot do anything against it, further cementing the new reading of the imperative to destroy idols as a prohibition against using them, since destruction of individual idols is cosmically futile. These three dialogues therefore form a secondary layer in the

${ }^{61}$ See Rosen-Zvi, "High Places."

62 See the restrictions in $m$. Avod. Zar. 2:1-2 and $t$. Avod. Zar. 3:1-10. Gentiles are suspect of murder, bestiality and adultery (2:1-2); even barbers, stable hands and wetnurses are suspect of these heinous sins. This has nothing to do with their idolatry; it is portrayed as a characteristic of the fact that they are not Jewish. The very laws of the Gentiles are perverted; see Berkowitz, "Limits," and the texts cited there. Noam Zohar recently read the tractate completely differently. See Zohar, "Partitions around a Common Public Space: Gentiles and Their Statues in Mishnah Avodah Zarah" (Heb.), Reshit 1 (2009) 146-163. He made some exceptional points, especially his method of reading "tapestries" in the tractate as whole units with literary sensitivity, as well as his observation that some of the heaviest restrictions in the tractate can be understood as leniencies compared to previous legislation. However, his reading was heavily influenced by Halbertal, "Coexisting," and by an apologetic agenda. Additionally, he was not attentive to issues of higher criticism in the tractate and read it all as one. 
tractate, at odds with some of its details but at the same time grounding, justifying and radicalizing its most basic - and audacious - claims.

Did the redactor(s) understand the import of their work? ${ }^{63}$ Perhaps, but this is largely immaterial. The dialogues are clearly not cut of the same cloth as the rest of the tractate, and the joining of the collections of mishnayot with the dialogues created the tractate as a whole, as we know it today. ${ }^{64}$ This is an example of redactorial work, the kind of work that wove individual strands of oral traditions into a multi-voiced tractate.

\section{E. A Concluding Note}

The role of aesthetics in the Mishnah has recently taken a central place in scholarship, as the Mishnah has become a focal point of study not merely as a collection of traditions or laws, but also as a work with literary properties. The place of narratives in the Mishnah has been studied extensively by Moshe Simon-Shoshan, who brought earlier studies not only to firmer theoretical footings, but to actual fruition, by realizing the central role of narrative in legal discourse, and in the Mishnah especially. ${ }^{65}$ The place of aesthetics and literary organization in the Mishnah has been highlighted by Avraham Walfish, Noam Zohar and Menahem Kahana. ${ }^{66}$ At first glance this reading seems to value the

${ }^{63}$ Cf. Simon-Shoshan, "Halacha," 213: "It may be that the editors of the Mishnah were fully aware of the implications of what they were doing. They purposefully formulated laws in a way that would allow maximum flexibility for interpretation and application by future generations of halachists. They sought to present their own authority in a nuanced way, warts and all, in order to present the Mishnah's students with a sophisticated and realistic model for the functioning of rabbinic authority. In this reading, the Mishnah argues that rabbinic authority stands despite challenges to centralized authority and the ultimately subjective and ambiguous nature of rabbinic rulings."

64 Although I contend that they were inserted into the tractate together, as part of the redactorial process, this is not necessary for my argument about the stylistic function of the dialogues. Regardless of the date of the insertion of each dialogue into its respective host-collection, and the connection between all three dialogues, the impact they have on the tractate as we have it is unmistakable. We also know that by the time of the earliest Amoraim, all of these dialogues - unlike the glosses (see above, n. 25) were firmly in place.

65 Simon-Shoshan, "Halacha"; for earlier studies see idem, 2-7, and also Yonah Frankel, "Aggadah in the Mishnah" (Heb.), Mehkerei Talmud 3 (2005) 655-683.

${ }^{66}$ Avraham Walfish, "The Method of Literary Redaction in the Mishnah" (Heb.; PhD diss., Hebrew University of Jerusalem, 2001); Noam Zohar, Besod ha-yetzira shel sifrut hazal (Jerusalem: Magnes, 2007); as well as Zohar, "Partitions," and Menahem Kahana, "The Mishna and the Order of Its Tractates" (Heb.), Tarbiz 66 (2007) 29-40. 
Mishnah as a whole, shying away from higher criticism, while quietly acquiescing with the results of critical inquiry into lower criticism. A similar turn towards lower criticism was initiated by David Rosenthal and his students. ${ }^{67}$ But the questions of higher critics that focus on the creation and development of texts are still relevant. A revamped higher criticism, combining its sensitivity to stratification and periodization in texts with literary and aesthetic criteria, as we have done here, is a handy tool for answering these questions, perhaps with surprising results.

This paper examined three dialogue-stories, and it is important to note that the use of this format in highlighting the problems the rabbis had with their own laws of idolatry is not coincidental. As we pointed out in our analyses, the dialogues make it possible both to voice discontent and to dismiss it; they allow for the articulation of good arguments in a way that makes them ludicrous. The reader knows to beware of the argument, while acknowledging it as possible and even plausible. This perhaps reflects the way Jews are expected to interact with Gentiles. They will no doubt make arguments, and one should know that the arguments should be dismissed from the onset.

Ishay Rosen-Zvi, in his recently published Demonic Desires, points out that arguments attributed to the evil yetzer are often those that point out real flaws in rabbinic theology and discourse. ${ }^{68}$ Thus, for example, the idea that God cannot find the sinners in Sheol - an idea backed by much biblical precedent - is attributed in m. Avot 4:22 to the yetzer. The rabbis disagree with this idea but do not want to confront it head-on. They attribute it to the yetzer to avoid the argument. Similar kinds of flaws in the halakhic system itself are marked here with dialogues with or about Gentiles. The redactors of the tractate used the dialogue not to create a conversation but rather to end it before it began. ${ }^{69}$

The real dialogue in the tractate, however, is not between the characters in the dialogue-stories, but rather between the laws and the stories. The laws are both undermined by the stories and undergirded by them.

See also the important remarks of Ishay Rosen-Zvi, "Orality, Narrative, Rhetoric: New Directions in Mishnah Research," AJS Review 32 (2008) 235-249, and the studies he surveys in n. 1 .

${ }^{67}$ See Rosenthal's remarks at http://jnul.huji.ac.il/dl/talmud/rosenthal.htm.

68 Demonic Desires: "Yetzer Hara" and the Problem of Evil in Late Antiquity (Philadelphia: University of Pennsylvania, 2012) 87-101. The discussion of Sheol is on pp. 91-93.

69 The monologic qualities of the Bavli's dialogues have recently been described at length by Barry Wimpfheimer, Narrating the Law: A Poetics of Talmudic Legal Stories (Philadelphia: University of Pennsylvania Press, 2011); see especially the methodological introduction on pp. 13-25. More research is required to examine this thesis, as well as its applicability to other rabbinic works. 
They exist in a tension that holds the tractate together. These dialogues could perhaps also be read as a reflection of the way the rabbis understood their interactions with Others. In fact, these interactions are mere reflections of the interactions between the rabbis themselves, inside the study house. Cheese, wine, statues and Gentile interlocutors may perhaps just be a backdrop for the real drama: the rabbis in conversation with each other. 